THE TYNDALE BIBLICAL ARCHAEOLOGY LECTURE 1973*

\title{
ALEXANDRIA TROAS
}

By C.J. HEMER

The substance of this lecture falls into two parts. In the first some account of a neglected New Testament city in the context of the historical geography of its district is attempted. This will illustrate the singularly strategic part it was equipped to play in the dissemination of Christianity. Then such aspects of several New Testament critical problems as may be clarified by the study of their setting in this city will be discussed.

The fame of Alexandria Troas has been overshadowed by that of its neighbour Ilium or Troy. Many early travellers visited it in their search for Troy, and some identified it as Troy. ${ }^{1}$

Their error rested in part upon problems in the ancient authorities. Troy itself has in any case nothing of the visual scale and splendour with which the poetic imagination has endowed it.

It is one of the minor mysteries of New Testament history that the site of Troas has been so strangely neglected subsequently. The starting point for any new study must be the short

*Delivered at Tyndale House, Cambridge, 11 July 1973.

${ }^{1}$ See now J.M. Cook, The Troad. An Archaeological and Topographical Study, Clarendon, Oxford (1973) $16 \mathrm{ff}$ for full discussion; cf. W. Leaf, Strabo on the Troad, Cambridge U.P. (1923) 238. The very recent publication of Professor J.M. Cook's detailed survey of the district will be of great value. His 51/2-page section on Alexandria Troas is largely devoted to the topography and the accounts of earlier travellers. He emphasizes the difficulty of writing any history of the site in default of extensive excavation. Indeed, a study like the present is from one point of view premature: in another aspect it is the more important to guard against misconception by the attempt to clarify what is and what is no known. And this study seeks to make a connection with New Testament questions which lie outside Cook's purpose. 
account in W. Leaf, Strabo on the Troad, Cambridge U.P. (1923) 233-240. Leaf's valuable book was the only volume ever published of a projected series of topographical commentaries on Strabo's description of Asia Minor.

The neglect of Troas is doubtless partly due to the remarkable deficiency of the usual sources of information. Strabo's Geography is the principal primary literary source. The geographer devotes a quarter of his whole account of Asia Minor to the Troad, only perhaps one-sixtieth of its total area (Leaf, xxv). Yet he dismisses Troas, the largest city of the area in his day, in a few words, and only gives information about it in a confused parenthesis when dealing with Ilium (13.1.26 $=\mathrm{p}$. 593). ${ }^{2}$ This extraordinary omission is discussed by Leaf (xxxixxxii). Strabo was more interested in the historical glories of Troy than in this upstart commercial seaport, ${ }^{3}$ and his source is Demetrius of Scepsis, a man who bore Troas a grudge for temporarily absorbing his own city and who accordingly treated it with silent contempt.

2 A textual problem is involved here. In the MS text as it stands Lysimachus' building of a five-mile (40-stade) circuit of walls and his synoecism of lesser cities are apparently ascribed to Ilium, but the writer immediately proceeds to speak explicitly, but with no mark of transition, about Alexandria. The facts previously stated are also demonstrably true of Alexandria, but appear to contradict Strabo's own words in his next paragraph if applied to Ilium. Grote long ago noticed the incongruity and drastically reordered the text to make the whole apply to Alexandria (Leaf, p.142). The vigorous debate in the 1880 's between Mahaffy and Jebb centred, as ever in this matter, on the interest in Troy rather than Troas, but Mahaffy, 'The Site and Antiquity of the Hellenic Ilion', JHS 3 (1883) 69-80, doubted Grote's rearrangement and sought to apply the whole to (Novum) Ilium, which he rightly equated with Homer's Troy. Leaf deals more simply than Grote with the textual problem, merely supplying 'Alexandria' with $\pi \delta$ ' $\lambda \varepsilon \omega \varsigma$ at the beginning, and eliminating the phrase which introduces it awkwardly later. He toys with the idea that the whole explicit Alexandria passage was a gloss giving correct information by one who realized that the previous statements applied to Alexandria. Cook does not appear to discuss the passage, but accepts that Lysimachus absorbed lesser towns into Ilium (p. 100). The walls of Hellenistic-Roman Ilium, as traced by Schliemann, were only in fact about $3 \frac{1 / 2}{2} \mathrm{~km}$. (=c.18 stades) long (Cook, p. 99).

The different but linked matter of the identity of Hellenistic-Roman Ilium with Homeric Troy also arose in Strabo, who commended at second hand the arguments by which Demetrius of Scepsis separated them $(13.1 .25=p .593)$. This however is not our concern here, and this question was long since settled in principle by Schliemann's discoveries at Ilium, though it was long before they stilled the debate.

${ }^{3}$ This selective interest is characteristic of ancient writing. $C f$. similar problems arising in the topographical methods of Pausanias: see E. Vanerpool, Hesperia 18 (1949), 128-137, cited and discussed in C.J. Hemer, 'Paul at Athens. A Topographical Note', NTS. 20 (1973-4) 347-348. 
Other ancient references are few and unimportant. Epigraphic materials are sparse and scattered. But so far as I know no attempt has been made to assemble a complete list even of those readily accessible in the Corpora.

The most informative class of evidence is probably the coinage. This gives some chronological framework, and is the best guide to the religion and inner character of the city. It is also a difficult class of evidence to handle, and in fact materials datable in the century of the New Testament are sadly lacking.

Modern study has done little to remedy the deficiencies. Ramsay's monumental Historical Geography of Asia Minor, London, John Murray (1890) fails us here. He simply remarks that at the time of writing the area forming the later Roman province of Hellespontus, which included most of the Troad, was entirely unknown to him (153).

Hirschfeld's article in Pauly-Wissowa is only a short paragraph which gives little help.

The new edition of the $O C D$ has no entry at all for it under 'Alexandria' or 'Troas' or in the index.

There is little more on the New Testament side. Troas is represented as the venue of some interesting and perhaps pivotal events in the history of the early Gentile mission. Some of their broader critical implications have been much discussed, but the strategic position of the city in the dissemination of Christianity has been little noticed since Ramsay's speculations in St. Paul the Traveller. ${ }^{4}$ There is not one entry in the recent exhaustive bibliography by A.J. and M.B. Mattill ${ }^{5}$ which deals with the central themes of this paper, and little which relates at all to the setting of events located in Troas.

Some of the consequences of this neglect are unfortunate. Some of the most fundamentally attested facts fare ill at the hands of recent writers. Two very simple examples must suffice here. Troas, we know, was a great seaport, and we are explicitly told that it was founded by Antigonus, one of Alexander's successors (Strabo 13.1.26 = p.593). In the latest edition of the Encyclopaedia Britannica it rates 3 lines. Apart from a note of the city's position and the date of its foundation as $334 B C$, in the lifetime of Alexander, the only state-

${ }^{4}$ Sir William M. Ramsay, St. Paul the Traveller and the Roman Citizen, Hodder and Stoughton, London (1896) 198-205.

${ }^{5}$ A Classified Bibliography of Literature on the Acts of the Apostles (New Testament Tools and Studies, ed. B.M. Metzger, Vol. 7) Brill, Leiden (1966). 
ments made there apply to Troy and not to Troas. ${ }^{6}$ But that is a small margin of error. A standard Bible Atlas, published in $1969,{ }^{7}$ assigns to Troas ruins dating from the third millennium $B C$, marks it on maps at three differing sites at periods from the Hittite to the Roman, and distinguishes it from the 'little town' of Alexandria hē Troas [sic]. On the New Testament associations of Troas we find 'It can hardly have been the apostle's point of departure for Macedonia. Troas lies about 3 miles from the sea and has never been a port."8

It should not be thought that this lecture concerns a mirage; let me reaffirm that there was a seaport named Troas.

In one sense these misunderstandings, which rest directly upon a history of complex confusions between Ilium, alias Troy, and Alexandria, surnamed Troas, are unimportant. In another sense it is a serious matter when historical criticism may be grounded upon data which are faulty. We should not be too severe on those who have repeated an erroneous tradition. It is surprisingly hard to reproduce facts accurately in one's own style, if paraphrasing or adapting a source, a factor not without relevance to the source criticism of the Acts. The difficulty is compounded when we stand remote in time and place. Our evidence is fragmentary and sometimes unrepresentative. Many of the simple data may hinge on the delicate appraisal of partial or circumstantial evidence. Whatever opinion we hold may need a complex justification. Such historical study is not the easy matter it sometimes appears in the commentators. It is desirable to endeavour to achieve a representative view of the whole context.

\section{II}

The character and importance of Troas cannot be understood without some prior account of its district. The north-western bastion of Asia Minor forms a rectangular promontory of land, some fifty miles across, which reproduces in miniature several

6 The 14th ed. (1929) has a short paragraph which is perfectly correct and rightly calls Troas the main seaport of NW Asia Minor. Both versions are unsigned.

7 J.H. Negenman, New Atlas of the Bible, Collins, London (1969). Contrast the anachronistic marking of Troas on maps on pp.24, 50 with the different placing on $\mathrm{p} .116$ and the true position on pp.171, 174, 179. $B C$ ).

P.172. The accompanying photograph shows the six th city of Troy (c. 1200 
of the geographical features of the land as a whole. Its northwestern margin is marked by the Asiatic shore of the Dardanelles, and the strategic and commercial importance of the Straits has given the district an importance in world history out of all proportion to its size. ${ }^{9}$

In primitive times Ilium, or Troy, commanded the mouth of the Dardanelles and presented a barrier to Greek expansion into the Black Sea. The legend of the Golden Fleece reflects very early Greek aspirations to enterprise beyond the Straits. ${ }^{10}$ The historical reality behind the Trojan War stories illustrates the same factors. ${ }^{11}$ And when the way was open, Aeolic colonization lapped the shores of the Troad, Miletus founded Abydus within the strait, and Phocaea Lampsacus, and Megara established Chalcedon and Byzantium on the Bosporus. A further wave of Milesian settlement and commerce colonized Sinope and Trapezus on the distant Pontic coast. ${ }^{12}$ Later the wheat-lands of the Euxine became an indispensable source of imported food for maritime Athens. ${ }^{13}$

Ancient navigation in this area was beset with peculiar difficulty. The theme is one of great importance to our study, and little attention has been directed to it. ${ }^{14}$ Sailing ships

${ }^{9}$ For a general description of the Troad and the elements of its historical geography see Leaf, $o p$. cit., Introduction.

${ }^{10} C$ f. P. Giles in $C A H$ 2.18f; J.B. Bury in ibid. 2.475, 478. The Jason legend apparently goes back to Mycenaean times. The 'fleece' is suggested to have been rain-washed gold or golden grain. Rich gold and bronze objects of Mycenaean type, from the 16th and 15 th centuries $B C$, have been found $W$ of Tbilisi (Tiflis) (M. Grant, The Ancient Mediterranean, Weidenfeld and Nicolson, London (1966) 108-9).

${ }_{11}$ The causes of the struggle have been much discussed. It is particularly hard to disentangle the possible elements of trade and colonial expansion, in both of which spheres Troy may have presented a barrier to the Greeks. The economic view developed impressively by Leaf in Troy $261 \mathrm{ff}$ and in Homer and History $288 \mathrm{ff}$, and the somewhat different emphasis of Ramsay (CR 18 (1904) 166), were alike criticized radically by C.A. Maury, 'The Leaf-Ramsay Theory of the Trojan War', CJ 12 (1916-17) 456-466. See also the replies by Leaf and Ramsay in $C J 13$ (1917-18) 66-71. We must agree with them that commerce is likely to have penetrated the straits early.

12 J.L. Myres in $C A H 3.657 \mathrm{ff}$.

13 For the importance of the corn-lands $c f$. $C A H$ 3.665. Cf. P.N. Ure in $C A H$ 4.103f on the importance attached by Athens to control of the area even in the 6th century through Miltiades, tyrant of the Chersonese.

14 On the problems of ancient navigation generally see the classic by James Smith, The Voyage and Shipwreck of St. Paul ${ }^{3}$, Longmans, Green and Co., London (1866), esp. 175-236. Many later treatments of the data, even by scholars of the calibre of Ramsay, have been justly criticized by L. Casson, 'Speed under Sail of Ancient Ships', TAPA 82 (1951) 136-148. 
were square-rigged, well adapted to utilise the regular summer winds of the Mediterranean over well-used routes, but quite unable to proceed at less than seven points into a head-wind. The vessel approaching the Dardanelles from the south met the northerly winds which prevail throughout the summer sailing season, and also faced the swift southward-flowing current of the straits themselves. ${ }^{15}$

It is sometimes difficult to visualize how the channels of ancient life were directed or diverted by natural forces which we can afford to ignore. Yet the essential limitations governing Mediterranean navigation remained substantially unchanged until the age of steam. ${ }^{16}$

In early days it may have been necessary to make the northward journey overland past Troy. It was always essential for ships to have some convenient shelter from which they could take advantage of any easing or veering of the wind for a swift run to Abydus within the strait. But the west coast of the Troad south of Troy has many miles of low exposed clayey cliffs with no good natural harbour north of Cape Lectum. This made the offshore island of Tenedos, which commands the entrance to the Dardanelles, important to shipping despite the poor shelter of its harbour. ${ }^{17}$ In Tenedos or Abydus the weatherbound sailor might be delayed for days or weeks.

Meanwhile the real focus of indigenous life from early times would have been at the temple of Apollo Smintheus. The cult is mentioned in the Iliad $(1: 37-39)$ as located in Tenedos and at Chryse. Chryse lay some five miles northeast of Cape Lectum, in the territory of the city of Hamaxitus. This site remained in the time of Strabo the religious centre of the whole area. This continuity must be emphasized. In Anatolia the temple-village came before the city: the Hellenized polis and the commercial seaport were peripheral and even

15 Grant, p.82, says that the 4 to 5 m.p.h. current in the Dardanelles is reinforced for 9 months of the year by strong NE winds. See further Appendix 2.

16 The point may be abundantly illustrated from the time of the Odyssey. Shipping had no effective choice but to run before a wind too strong or too far ahead. For the seasonal limitations on various kinds of shipping $c f$. Philo, Leg. ad Gaium 33.251; Vegetius, Epit. Rei Milit. 4.38-39.

17 A small roadstead might serve in the earliest times, as at Chryse in Hom. $I$. $1.430 \mathrm{ff}$, but this was unsafe for larger vessels. For the limitations of Tenedos see Leaf, pp. 214-216, and Strab. 13.1.46 = p.604. Cf. Verg. Aen. 2.23: statio male fida carinis. 
alien developments from the standpoint of the static agricultural or pastoral native economy. ${ }^{18}$

Coinage testifies to the growth of several considerable cities in the western Troad by about the fifth century $B C{ }^{19}$ Most prominent at first were Scepsis and Cebrene in the hinterland, bitter rivals for ascendancy in the upper basin of the Scamander. The route between them and the west coast was dominated by the fortress of Neandria on the culminating 1600-foot ridge of Chigri Dag. The coins of the two coastal towns of Colonae and Hamaxitus are fewer and apparently later. ${ }^{20}$

Despite the great importance of the neighbouring straits these towns of the hinterland were of only local importance. The Troad is an area of abundant economic resources but of poor and peripheral communications. ${ }^{21}$ The district under discussion was separated from the south and east by rugged watersheds formed by the northern and western offshoots of Mount Ida, and divided internally into isolated basins within the line of a peripheral scarp. ${ }^{22}$ Only Scepsis made some mark in the wider world. It appears to have received Ionian colonists after the sack of Miletus in $494 B C$; it was a respectably assessed member of the Delian League, although so far inland; and it achieved some reputation as a cultural centre. ${ }^{23}$

We must pass over the incidents of the prolonged struggle of Athens to keep control of her strategic lifeline through the Hellespont in the face of Spartan and Persian challenges. The cities of the western Troad are scarcely mentioned except in a campaign of $399 B C$ when the satrapess Mania, acting for the Persian Pharnabazus, seized the three coastal towns of Larisa,

18 On the patterns of Anatolian settlement $c f$. W.M. Ramsay, The Historical Geography of Asia Minor, John Murray, London (1890) 84f; 'The Permanence of Religion at Holy Places in Western Asia', Pauline and Other Studies, Hodder and Stoughton, London (1906) 163-188; and the history of numerous sites described by him elsewhere.

19 W. Wroth, BMC Troas, Aeolis and Lesbos, London (1894) passim.

20 On the principal sites of the district see now Cook, pp.204-208 (Neandria), 216-221 (Colonae and Larisa), 228-231 (Smintheum), 231-234 (Hamaxitus), 327344 (Cebren), 345-347 (Scepsis).

21 The point is little noticed. $C f$. however Grant, pp. 83-85, who remarks on the deficiency of the inland communications of the district, and attributes to the inaccessible mountainous hinterland the fact that Troy was destroyed only twice in 2000 years.

22 Leaf, xvi-xviii, with orographical map.

23 See further Leaf, 'Skepsis in the Troad', Anatolian Studies Presented to Sir William Mitchell Ramsay, ed. W.H. Buckler and W.M. Calder, Manchester UP (1923) 359-390. 


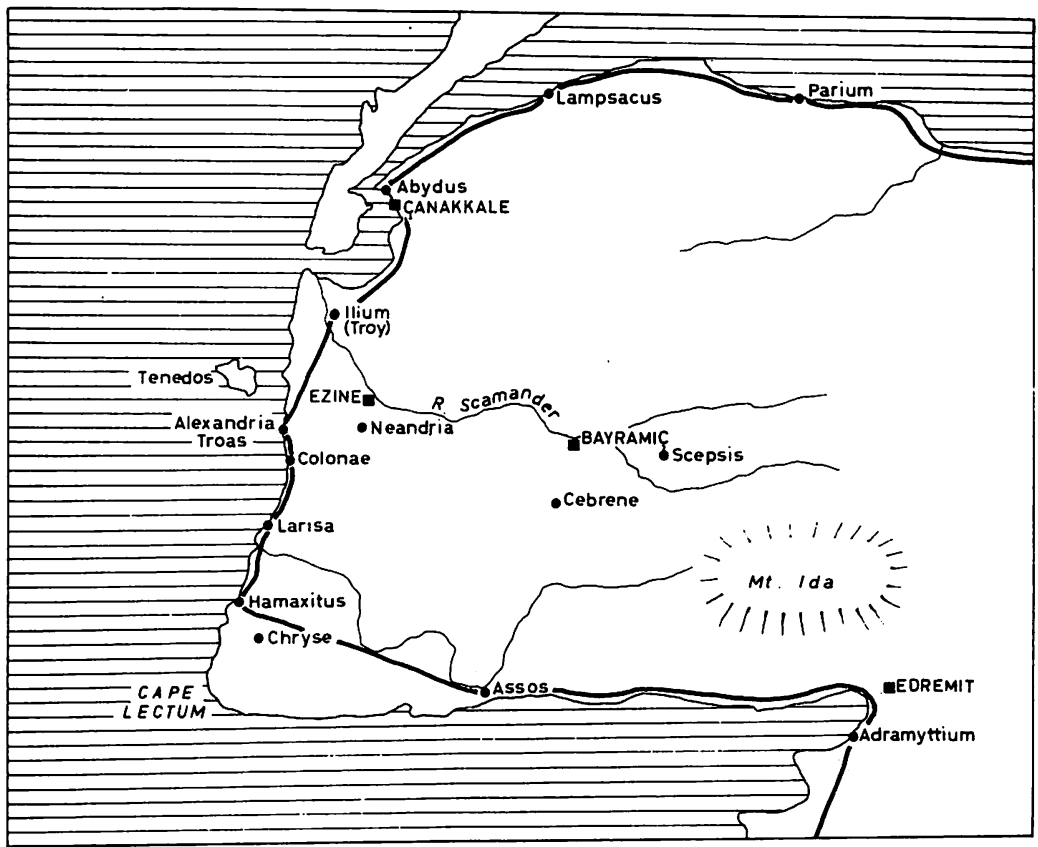

Hamaxitus and Colonae (Xen. Hell. 3.1.13). On her murder by her son-in-law Midias, the enterprising Spartan Dercyllidas gained the three in a day and won over Neandria, Cebrene, Scepsis and other places so swiftly that he was said to have taken nine cities in eight days (Xen. Hell. 3.2.1). This episode gives a glimpse of the grouping of cities in a self-contained district and accords well with the pattern of the coinage of similar date. ${ }^{24}$ The Persian grasp weakened, and when Alexander crossed the Hellespont a new era began. It issued all too soon in the bitter struggles of his Successors, when Antigonus held the Troad against Lysimachus.

It is ironic that two of the few extant inscriptions of Scepsis concern Antigonus' promise to restore freedom to the cities, evidently on the occasion of the peace concluded in $311 B C .^{25}$ The king's letter is an elaborate justification of his policy: the city decree heaps him with extravagant honours as the author of her new peace and freedom. The same Antigonus shortly

24 BMC passim.

25 J.A.R. Munro, 'A Letter from Antigonus to Scepsis, 311 B.C.', JHS 19 (1899) 330-340. 
afterwards transplanted the populations of Scepsis, Cebrene, Neandria, Colonae and Hamaxitus into a new city which he built on the west coast and named Antigonia. After his death at Ipsus in $301 B C$ his rival Lysimachus devoted his attention to this place, built there a temple and a city-wall forty stades (or five miles) in circumference, and believing that piety required that the successors of the great Alexander should found their cities under his name rather than their own, he renamed it Alexandria (Strab. 13.1.26 = p.593). Although transferring into it some unspecified old and decayed towns of the district, ${ }^{26}$ he wisely permitted the Scepsians to restore their own city $(13.1 .52=$ p.607). The new Alexandria grew and flourished: in Strabo's time (d. about $A D 20$ ) it was one of the famous

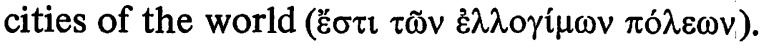

The source of this prosperity is not far to seek. We must ascribe to the Hellenistic founders of Alexandria Troas the construction of the fine artificial harbour which provided for the first time a secure shelter within a few miles of the mouth of the Hellespont. ${ }^{27}$ A circular basin some 400 yards in diameter was cleared, possibly on the site of a natural marsh or lagoon, and joined with the sea through a smaller outer basin, now silted up. Apart from the decisive advantages of this new seaport for commerce to the Dardanelles, it provided also a direct sea-passage from Macedonia to the coast of Asia, a link of great potential importance in the new political and economic patterns of the Hellenistic world, and one which avoided the need to brave the Thracian tribes of the land-route. The scale of the Lysimachean walls is a testimony to the remarkable size of the original foundation: Strabo's estimate accords pretty well with the actual remains, which may still be traced for much of their course. The seaward face of the walls must have extended nearly two miles to the south of the harbour at the north-west angle of the city. Leaf estimated that the enclosed area was about 1000 acres, and at the conjectural reckoning of 100 persons per acre that gave him a population

26 I assume here the understanding of Strabo which refers these words to Alexandria, not to Ilium.

27 There is to my knowledge no conclusive evidence for this dating, but the harbour was essentially the raison d'etre of the town and the necessary source of its growth. And the adjoining walls are apparently ascribed by Strabo to the Lysimachean foundation. 
of $100,000 .^{28}$ This can be no more than a guess, and may well be too high a figure. But it gives some notion of the scale of the place we are dealing with.

Today this huge site is deserted. The visible remains are strangely few and mostly unimpressive, though of wide extent. Their setting is now one of extreme beauty: the ground slopes gently to the sea, and is almost wholly covered with an open park-like forest, mainly of vallonia oaks. The trees and the subdued contours preclude any very general view. ${ }^{29}$ Apart from the walls little or nothing pre-Roman may be seen, and the most conspicuous building is the Baths of Herodes Atticus (second century $A D),{ }^{30}$ known to enthusiasts of the preSchliemann era as the 'Palace of Priam'. Troas was identified with Troy before Troy came to be identified with Troas.

The very few literary references to the early years of the city illustrate its swift rise to importance. When Ilium was beset by the marauding Gauls about $216 B C$ (Polyb. 5.111.3-4; context referring to 140 th Olympiad), the siege was lifted by the gallantry of the men of Alexandria Troas, who sent a relieving force 4000 strong. The incident testifies to the strength of the city and perhaps also to its vital concern with the safety of the straits. A little later this city was one of three which are represented as the key points of contention in the struggle between Rome and Antiochus the Great. At first only Lampsacus and Smyrna are named, both very great cities (Polyb. 18.49-52; Liv. 35.16.3ff). Eumenes II of Pergamum, the ally of Rome, upheld the freedom of the cities as a check on Seleucid ambitions. Alexandria Troas is subsequently named with the other two as having been the occasion of the final struggle between Rome and Antiochus which ended at Magnesia in $190 B C$ and made Rome potential mistress of the East (Polyb. 21.13.3 = Liv. 37.35.2 = Diod. Sic. 29.7): Antiochus had been unable to win these three by assault or by negotiated friendship (Liv. 35.42.2).

The picture is slightly enlarged by the evidence of the coinage. I find no record of the existence of issues under the name 'Antigonia' (Wroth, $B M C$, p.xiv): there is however extant

28 Leaf, p. 236.

29 See Cook, pp.199-200, on the progressive obscuration of the site by the growth of trees.

${ }^{30}$ For this building see the study by R. Koldewey, 'Das Bad von Alexandreia Troas', Athenische Mitteilungen 9 (1884) 36-48. 
a Neandrian coin countermarked $A \Lambda E \Xi A N$, an indication that currency of the absorbed cities circulated there even after the change of name under Lysimachus. And the numerous early types with the name Alexandria imitate the latest autonomous designs of the older places, notably the Apollo Smintheus types of Hamaxitus and the feeding horse of Neandria. ${ }^{31}$ Variations of both motifs continue through the whole subsequent history of Troas, as the Smintheum continued to be the cultic centre of the territory which was now politically dependent on the new city.

Eumenes, the former champion of the Greek cities against the Seleucids, was happy enough to absorb them himself when opportunity offered ( $c f$. Polyb. 21.22.7ff): in the settlement after Magnesia he duly received 'Hellespontine Phrygia' (21. $45.10 ; c f$. Strab. $12.4 .3=$ p.564). Rostovtzeff has contributed a valuable study of the economic policy of the Pergamene kings, and this stresses the crucial importance of the Troad to them. ${ }^{32}$ They saw themselves as rulers of a military and strategic entity whose resources were largely located there. ${ }^{33}$ Control of the Hellespont and the friendship of Cyzicus were necessary to their Pontic trade, especially in iron. The Troad itself was their principal source of metals, of timber and pitch for shipbuilding, and of cavalry horses. ${ }^{34}$ We recall the characteristic motifs of the coins of the old cities absorbed in Troas: the feeding horse of Neandria, the conifer and winged horse of Scepsis. ${ }^{35}$ King Attalus I himself is known to have written on the pine forests of Mt. Ida; he is quoted on the subject by Strabo $(13.1 .44=p .603)$.

Nothing explicit is recorded of the fortunes of Alexandria Troas during this period, but its importance to the Attalids is evident. It was the key to the approach to the Hellespont and also the coastal outlet for the strategic materials of its immediate hinterland. Yet this may not have been an unmixed blessing. The centralising policy of the dynasty tended to encroach

31 The latter motif continues as the mint-mark of Seleucid coinage attributed to this mint under Antiochus II (261-246; BMC Seleucid Kings p.xxx and Ant. II Nos. 5-7).

32 M. Rostovtzeff, 'Notes on the Economic Policy of the Pergamene Kings', Anat. Stud. Ramsay, 359-390.

${ }^{33} C f$. the concept of the Attalid monarchy as a continuation of Orontes' satrapy of Mysia (cf. OGIS 264a.4ff; Rostovtzeff 363).

34 Rostovtzeff $365 \mathrm{ff}$.

35 BMC passim. 
upon the cities, and yet there was no secure peace for the development of their commercial potentialities. The Attalid interest in the area remained essentially military. Alexandria is represented throughout the period and into the Roman time only by a few coins of silver and bronze, some dated, but from a doubtful era. ${ }^{36}$

It is against this kind of setting that we can begin to appreciate the favourable changes wrought in this neighbourhood by the pax Romana. The Caesars were moved by far more than the traditional link of Rome with Troy. They appreciated both the strategic significance and the potential vulnerability of the Straits. And on the security of this area hinged the development of rapid and regular communications between Rome and the East. It was actually rumoured in Rome, according to Suetonius (Caes. 79.3) that Julius Caesar intended to move the government of the Roman world 'to Alexandria or Ilium' - where Alexandria evidently means Alexandria Troas: later Horace in a great national ode had to decry the idea, apparently in the face of the persistence of a belief that Augustus intended to make a similar move (Odes 3.3. esp. 57-68).

We have some striking evidences of the activities of the earliest emperors in the district. Augustus created two new Roman colonies at the approaches to the opposite ends of the Hellespont, at Parium to the north-east, ${ }^{37}$ and, inevitably, at Alexandria to the south. The city is henceforth formally designated on its coins and epigraphy 'Colonia Augusta Troadensium' or simply 'Colonia Augusta Troas'. ${ }^{38}$ Troas is henceforth the name in ordinary usage: in Greek the ethnic

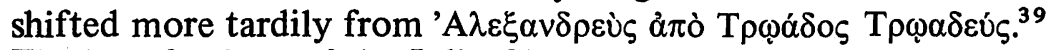
The benefactions of the Julio-Claudian period are reflected in a spate of dedications from Troas, Ilium and elsewhere. Ilium and her confederates erected a statue to the divine Augustus for his 'unsurpassed achievements and benefactions to all man-

${ }^{36}$ BMC Nos. 22-24 (silver, dated); Nos. 25-36 (bronze, undated).

37 The legend C G I P (Colonia Gemella Iulia Pariana) appears on coins of Parium from Augustus, often accompanied by the name of the colonial magistrate designated duumvir (BMC Mysia, Parium Nos.84ff).

${ }_{39} C I L 3.391$ and $B M C$ passim.

39 Contrast $C I G 3578,3588$ (pre-colonial) and Athen. Deipn. 4.155b; 9.393d with e.g. IGRR 4.246. On the latter $c f$. C. Habicht, Altertümer von Pergamon 8.3, Staatliche Museen, Berlin (1959), 'Die Inschriften des Asklepieions', on No. 74, p.111. 
kind'. ${ }^{40}$ Another inscription of Ilium honours a procurator ( andage in the Hellespont and protected the city freely, without exacting a price for the privilege. ${ }^{4}{ }^{1}$

We cannot enter here on the detail of the imperial initiatives designed slowly to pacify and Romanise the turbulent hinterland of Thrace to the point where Claudius formally annexed the whole in $A D 46 .^{42}$ By the time of Paul's travels the benefits of the new security were maturing: a series of Imperial dedications in Latin of the thirties and forties is represented among the sparse epigraphy of Troas (CIL 3.380, 381, 6060). The contemporary feeling is summed up in the words ascribed to Epictetus: 'Caesar has won for us a profound peace. There are neither wars nor battles, neither brigandage nor piracy, and we may travel at all hours, and sail from east to west

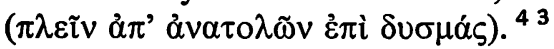

I emphasise that final phrase. It brings us back to the dependence of ancient shipping on the right winds. This whole subject calls for realistic study. I am much indebted here to a valuable article by L. Casson. ${ }^{4}{ }^{4} \mathrm{He}$ estimates for instance that under the persistent north-westerlies of the summer season in the eastern Mediterranean the voyage from Rome to Rhodes took 7-11 days, the reverse journey from 45 to 63 . We have to appreciate that Troas was a nodal point on what became a sophisticated system of international routes, organized functionally with regard to complex variables of speed and safety, of season and weather and conditions by land and sea. Yet the animating principle of the whole system was not, as yet, communication of province with province, but of each with Rome. Troas was the place where two highly important, but functionally different, routes from the East

${ }^{40}$ CIG $3604=$ IGRR 4.201; cf. CIG 3609, to M. Agrippa, who held wide powers as his regent in the East, perhaps $c$. 16-13 BC. G.E. Bean in Cook, pp.401402, No. 29, publishes a new dedication from Alexandria Troas to Agrippa's wife Julia, the daughter of Augustus, who accompanied her husband to the East.

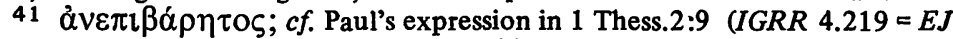
227). Another new discovery from the neighbourhood of Troas, a Greek fragment, has been conjectured to refer to the clearing of pirates from the Hellespont by the emperors (Bean in Cook, No. 41, p.407). The text is evidently metrical.

42 See $C A H$ 10.806; cf. Tac. Ann. 3.38-39; 4.46-51;OGIS $378=$ EJ 48.

43 Arr. Epict. 3.13.9.

${ }^{44}$ See n.14; $c f$. his 'The Isis and her Voyage', TAPA 81 (1950) 43-56. 
to Rome actually crossed. ${ }^{45}$ The swiftest, all-season landroute used by the imperial post included the short sea-crossing to Neapolis, seaport of Philippi in Macedonia, and thence by the Via Egnatia to the Adriatic coast and across to Brundisium. The sea-route from the Pontic lands to Rome ran from the Dardanelles across the Aegean and past Malea at the southern tip of Greece. On the northward voyage it must have been necessary to follow closely the coast of Asia to Troas, under the repeated risk of delay or even being blown back among the islands. This coastal traffic to the straits was evidently important at most periods. The same winds beset the Peloponnesian fleets (Thuc. 8.80, 99, 101), Herod on his way to join Agrippa (Jos. Antiq. 16.2.2.17-18), and Pliny explaining to Trajan his late arrival in Bithynia ( $E p .10 .15,17 \mathrm{~A})$. Delay was sometimes inevitable, but the safety of sea-travel was greatly improved by the provision of fine artificial harbours at Adramyttium, Assos and above all at Troas. ${ }^{46}$ There travellers by land and sea from many parts of the East must have converged to wait for a chance to cross to Macedonia en route for Rome or to enter the Dardanelles.

What kind of city was the Troas of New Testament times? The evidence for a detailed picture does not exist, but a selection of impressions may be useful. It seems probable that this city was singularly lacking in many of the characteristic institutions of Greek civic life. It was a cosmopolitan mixture whose elements were never well integrated, a Roman colony imposed on a population composed of the forcible amalgamation of disrupted older communities, and doubtless augmented by an unusually large number of the traders and sojourners drawn by its singular function in the system of communication. The indications are that the native population of the district, so far as it was represented in Troas, still found its cultural and religious focus at the Smintheum at Chryse by Hamaxitus, some fifteen miles to the south. There is, for instance, a sharp

45 See generally here W.M. Ramsay, 'Roads and Travel (in NT)', in HDB Extra Vol. $375 \mathrm{ff}$.

${ }^{46}$ See Leaf, p.291 ad Strab. 13.1.57 = p.610 (Assos) and p.319 ad 13.1.65= p.613 (Adramyttium). Leaf also argued for a shelter for shipping at Babakale, under the lee of Lectum, and placed Hamaxitus there (pp.227-229). The place would doubtless be exposed to the south, but the habitual danger was from persistent northerlies. Cook however locates Hamaxitus north of Lectum, and finds no authentic evidence of early occupation or harbour works at Babakale. 
demarcation, or even discontinuity, in the styles and subjects of the Greek and the Latin inscriptions of Troas, apparently. reflecting elements with wholly diverse interests. The Latin are intensely and very formally Roman dedications and epitaphs, sometimes erected by a numbered 'quarter' of the town (vic(us) $X$, etc.). The Greek are largely sepulchral, in the tradition of Anatolia which is concerned so strongly to invoke sanctions against the intrusion of an unauthorised burial: a very few yield gleanings of religious or agonistic interest, but are not closely datable. One of these associates Apollo Smintheus with Asclepius Soter (CIG 3577); another refers to a man whose statue stands 'both in the Smintheum and here in the Asclepium' (CIG 3582). I surmise that the Asclepium was the principal city temple, that Asclepius was equated with the native Smintheus as god of healing, an aspect of Apollo. It may be relevant to note that hot springs are sited within a mile south-east of the city. Another inscription, from the Smintheum itself, refers to games, the Sminthea Paulina, which were, in the view of L. Robert, a closed festival for the citizens of Troas, as distinct from the

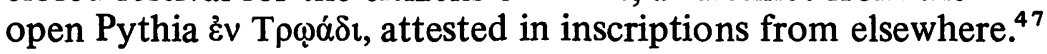
But we cannot affirm that these games were instituted as early as the New Testament period.

We have referred to the antiquity of the cult of Apollo Smintheus. An understanding of its origin and nature would perhaps tell us something of the local population. We cannot however pursue here this interesting but baffling problem of the 'mouse-god': was the mouse originally a tribal totem (Lang); or recognised as a carrier of plague, like the rat (Godley, Moulton); or a symbol of the suddenness of pestilence (Cree); or is the allusion to the destructiveness of irregularly periodic plagues of field-mice (Leaf and Farnell)? ${ }^{48}$ Was the god primarily a god of healing or of agriculture? We can only say that motifs from the cult predominate strangely on the later coinage of Troas, which never rid itself of the religious hege-

${ }^{47}$ L. Robert in Anatolian Studies Presented to W.H. Buckler, Manchester U.P. (1939) 245-248.

48 A.D. Godley, CR 15 (1901) 194; J.H. Moulton, ibid. 284; A.T.C. Cree, ibid. 284-285; A. Lang, ibid. 319-320; Leaf, pp. 243-245; L. R. Farnell, Cults of the Greek States, 4.162-166. 
mony of the Smintheum that it inherited with the absorption of Hamaxitus. ${ }^{49}$

Nor perhaps could it ever escape the historic and civic prestige of Ilium on the other side, which continued to hold the primacy in a religious league of confederate cities. ${ }^{50}$ Of the relation of the two cities in our period I have little information. It is strange that while the coins of commercial Troas have been noted to predominate even among those discovered at Ilium and far further afield, issues of the first century are absent, whereas Roman Ilium then coined freely. ${ }^{51}$

The one explicit incident relating to Roman Troas in secular sources belongs to the time of Hadrian. The young Herodes Atticus urged the emperor to permit him to spend 3,000,000 drachmae on a water-supply needed by this great city: the cost actually ran to $7,000,000$, and eventually had to be made up by Herodes' wealthy father (Philostr. Vit. Soph. 2.3).

Ruins of the baths survive: ${ }^{52}$ the great associated aqueduct has suffered as too easy a quarry for building stone.

The decline of Troas was probably signalled by the rise of the new Constantinople. Its colonial Latin evidently persisted as late as Arcadius (CIL 3.413, found at Smyrna, but evidently carried hence) a notable contrast with the earlier absorption of the colonies of the Pisidian region..$^{53^{\circ}}$. Leaf suggests that Justinian's granaries on Tenedos mark the date of the final silting of the harbour of Troas (p.221).

An ancient site is usually represented by a modern settlement, on the same site or at some distance, which in some

49 The coin-types of Troas are relatively few and repetitive, though the issues are numerous. Empty personifications like the 'genius' of the city constantly recur, interspersed with the cult-image of Apollo Smintheus with a mouse at his feet, and with enigmatic religious scenes, as where a herdsman stands before a cave containing a prostrate statue of the god, while a similar statue stands above the cave and a bull runs away, as if terror-stricken.

50 Delegates from seven confederate cities, including Alexandria, are named on an Ilian inscription of $77 B C$. (IGRR $4.197=$ OGIS 444). Cagnat (IGRR ad loc.) notes that Gargara and Parium are missing here from the list later made up to the

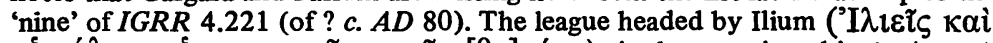

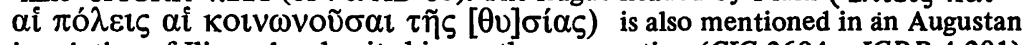
inscription of Ilium already cited in another connection (CIG $3604=I G R R 4.201)$.

51 BMC passim. Cook comments (p.202) that the Hellenistic coins of Troas apparently had a comparatively modest circulation, but that the colonial ones, mostly of the third century $A D$, are by far the commonest city-coins of the Troad.

52 See R. Koldewey, 'Das Bad von Alexandria Troas', Athenische Mittheilungen 9 (1884) 36-48).

53 Cf. B. Levick, Roman Colonies in Southern Asia Minor, Clarendon, Oxford (1967), 130-162. 
degree inherits its former importance. There is no considerable town at all today in this part of the western Troad. The small inland town of Ezine represents Neandria, if anywhere. Geyikli is small and still distant, Dalyan a mere hamlet of a dozen houses. The village of Kestambol, that is, Eski Istanbul (Old Istanbul) alone preserves in its mere name the memory of a great city. But Troas was an artificial city, which flourished upon its focal place in the special conditions of a passing era, and whose people simply dispersed when its peculiar advantages were dissipated. ${ }^{54}$

This outline, however tentative, gives a picture of a city which lacked the closely integrated structure of the typical Greek polis, where political, social and religious bonds were interwoven. Paul usually had the best starting-point for evangelism where strong Jewish communities existed and had rights and even influence in the city. It is very likely that there were many Jews in this city, but we have no information about them and can know nothing of their standing. But Paul's opportunity may have come here from the very heterogeneity of this city, whose diverse peoples often met as new settlers if not transient sojourners, absent permanently or temporarily from the close social pressures of their native places and therefore the more open to the influence of a new movement.

Luke does not describe the evangelization of Troas: perhaps he did not see it as representative of Paul's policy and method. Yet the results of preaching here were clearly important, for Troas is unexpectedly prominent in the New Testament texts.

\section{III}

The concept of a lecture in 'Biblical Archaeology' is perhaps a strange one. Even if we define archaeology in a suitably broad way it is questionable how far one may have a 'Biblical' archaeology essentially different from any other kind except in the purely accidental sense that it happens to impinge on areas of interest to Bible students. The aim should be to see a complete picture rather than to supply isolated data as

54 Cook (loc. cit.) mentions that Troas was an episcopal see in Byzantine times and that Piri Re'is speaks of infidels (Christians) leaving it at the Moslem conquest. He finds no trace of anything later than early Christian there: scarcely any Byzantine coins have been found. 
ammunition for the controversies of Biblical criticism. But the concept of Biblical archaeology also tends to have some presuppositions built into it. If we aim to create an integrated picture, we also tend to assume that the Biblical evidence will somehow correlate positively with that picture. The assumption is that the thing is worth doing, and that the answers are going to be in some degree positive ones.

But this is not to be a formula for a simplistic apologetic. A study involving such a book as the Acts must grapple with complex critical problems. In a lecture such as the present only a very few limited aspects of the questions which might be raised can be selected.

Troas is named in the New Testament only at Acts 16:8 and $11,20: 5-6$, and in 2 Corinthians $2: 12$ and 2 Timothy 4: 13 , all raising points of great critical interest, but not exhausting the possible relevance of our study. In one sense the proper place to begin ought to be on the solid ground of Paul's Hauptbriefe, in 2 Corinthians. But the ostensible chronological sequence begins in Acts, and the central crux is the consideration of the use we may be allowed to make of Acts. Here questions of presupposition arise in their sharpest form. I shall accordingly attempt to grasp at least a branch or two of this series of critical nettles by concentrating my attention in this final section mainly upon Acts 16:6-11.

Here begins the first of the 'we-passages'. Is this form an indication that the author of Acts was an eye-witness, or is it a redactional device of some kind? The question takes us immediately into the problems of the source-criticism of Acts. Here I must limit the area of the discussion, explaining merely the kind of position I should wish to uphold on the travel narratives of Acts while reserving the detailed justification of such a position for a much fuller study on a much wider front.

There is the phenomenon of the demonstrable accuracy of many insignificant details incidental to the narratives, a factor which the 'archaeological' approach has done much to clarify. This can be made the staple of a popular apologetic: Ramsay has been saddled here with the sins of those to whose applications of it he might have reacted violently. He used it rightly to establish certain things about the kind of writer Luke was, and to assist discrimination among the critical possibilities. Professor Haenchen in his monumental recent work (p.86 
and n.) emphasizes the pains which Luke took over his sources: it is an aspect which needs to be taken into account in giving an adequate account of Luke the historian-theologian. Haenchen explains it by the assumption that Luke took great trouble to inform himself by visits and letters to the principal Pauline churches.

I doubt the feasibility of this explanation. I cannot prove an alternative. It is a matter of personal judgement, of the evaluation of the possibilities. The whole source-question in Acts is singularly elusive, as Dupont has shown in his great work on the subject. ${ }^{55}$ What Luke has used he has made his own and adapted to his purpose. The same stylistic features, it is agreed, pervade the first-person as the third-person sections. And similarly inconsequential details are present in both. These phenomena are more easily explained, in my view, by the assumption that the writer was close to the events of the latter half of Acts than on any other hypothesis. He was, I think, a companion of Paul who had the apostle's own account of some occasions when he was not present in person, and he wrote at a time not far removed. I can readily understand how the earlier chapters of Acts were written from diverse and indirect sources, for they have not been so fully assimilated to Lukan forms: I can understand that numerous Western readings are redactional, for they betray secondary and explicative characteristics. But no complex hypothesis will, I think, particularly help to explain those parts which are both so Lukan and so inconsequentially circumstantial. We noted at the outset how unexpectedly difficult it sometimes is to reproduce simple facts of geography and history without absorbing their context. I have been haunted by this very difficulty in trying to make accurate factual statements about a subject so imperfectly understood as the historical geography of the Troas district.

On the (perhaps subjective) ground of my approach to historical criticism I see nothing to be gained here by more complicated hypotheses. Certain recurring phenomena become harder to explain the further the composition is removed from the date of the travels. A book like Acts could

55 J. Dupont, The Sources of Acts. The Present Position, Darton, Longman and Todd, London (1964), tr. by K. Pond from Les Sources du livre des Actes. Etat de la question, Desclée de Brouwer, Bruges (1960). 
have been written in $A D 80$ or $A D 100$ or later, but I beg leave to wonder whether it could have been quite the book we have.

But the present crux is the significance of the 'we-passages'. Do they testify to direct participation by the eventual author of Acts, or are they some kind of literary device? In the latter case, do they testify to the second-hand use of an eye-witness source, or are they inserted redactionally to point some theological motif?

Any estimate of Luke's purpose in writing must take account of the evidence of the words of his preface where he professes to state it (Lk. 1:3-4). Here I must mention in passing a view which I find attractive but quite inconclusive. H.J. Cadbury has proposed to render $\pi \alpha \rho \eta \kappa \circ \lambda \circ 0 \theta \eta \kappa o ́ \tau \imath$ in Luke $1: 3$ as 'having known by participation': it is to be inferred from the expression that the writer is here claiming to have been present at the later stages of the events he narrates. ${ }^{56}$ The strength of the case lies in its appeal to usage: it is notable that it was adopted by Moulton and Milligan from his earlier formulations of it, and extensively paralleled by them and applied illuminatingly to other instances of the word. ${ }^{57}$ But the view depends on too rigid an interpretation of the words, and it assumes that the preface to the first book focuses the reader's attention chiefly upon the author's qualification to write the latter part of the second. One must accordingly be cautious about using this preface to solve the 'we'-problem. It does however appear to insist on his concern with accuracy.

Haenchen has offered two different views of the first 'wepassage' in Acts 16:10ff. On the one hand he argues that the device points to an eye-witness source, for the verses Acts $16: 11-15$ are 'precise and graphic, and there is no reason to question their historical reliability'. 58 Alternatively, he suggests that the form marks emphasis on a significant juncture, the coming of the gospel to Europe. ${ }^{59}$ On the first

56 H.J. Cadbury, 'The Knowledge Claimed in Luke's Preface', The Expositor 8th ser. 24 (1922) 401-420 and in Beginnings of Christianity 2.489-510; more recently " "We" and "I" Passages in Luke-Acts', NTS 3 (1956-7) 128-132.

57 The Vocabulary of the Greek Testament, Hodder, London (1926) on $\pi \alpha \rho \alpha \kappa \circ \lambda$ ov $\theta \varepsilon \dot{\varepsilon} \omega$, citing Cadbury's earlier articles.

58 Studies in Luke-Acts, ed. L.E. Keck and J.L. Martyn, Abingdon Press, Nashville (1966) 272-273.

59 JTC 1 (1965) 82f. = ZTK 58 (1961) 347-349. 
view I follow Dupont in wondering whether the original readers could have understood 'we' in any other than a straightforward sense $:^{60}$ on the second I have to object that Luke makes no such emphasis on the Troas incident. But the point raises questions of usage, and it is on the nuances of the interplay of usages that we may often find the most objective, if not necessarily the most easily applied, historical criteria. The point merits some discussion from an example taken from this passage.

Four views of the meaning of the term 'Asia' in Acts 16:6 have been brought into the debate. (1) Ramsay and others have favoured allusion to the Roman province of proconsular Asia. (2) Haenchen in JTC 1 (1965) 82 paraphrases 'Asia' as 'Asia Minor' (Kleinasien in the corresponding ZTK 58 (1961), 347), a much larger area. ${ }^{61}$ (3) Haenchen again, in an argumentum ad hominem against Ramsay (Apostelgesch. 14th ed., p.424 n. = ET p.484 n.) says it 'means the same region as in the Revelation of St. John', by which he appears to understand 'the great cities on the west coast such as Ephesus', with an unspecified area of their hinterland (p.483 n., cf. p.486), that is, apparently an area much smaller than the province. (4) Haenchen again, in an argumentum ad hominem against Dupont (JTC 1 (1965) 82n.) takes the position that Luke is thinking of Asia and Europe as continents.

This kind of question should be settled by the evidence of usage. Haenchen appeals to it only in connection with view (4), citing clear evidence from Philo and Dionysius Periegetes ${ }^{62}$ against the assumption that the continents were not distinguished in first century thinking. His point might have been made

60 Dupont, pp.128-131.

61 Unless Haenchen understands Kleinasien in a very circumscribed sense. It is difficult to know how to take his expression 'only the road to Troas remains open' ( $J T C$, p.82), for Troas lay within the closed region of 'Asia' on all but the narrowest interpretation of that term, and conversely Troas was not a very natural destination in the circumstances postulated, as much more obvious routes led to nearer points on the coast both north and south of it. Haenchen does not discuss the real geographical problems, which have been overlooked through the simplistic following of data culled from Ramsay about an area of which he had little personal knowledge. There is not necessarily a difficulty in acknowledging that Paul was here in 'Asia' though barred from preaching there: but the choice of Troas as an objective merits closer study and more rigorous explanation than seems yet to have been offered.

62 Philo, Leg. ad Gaium 36.283; ad Flacc. 6.46. He cites Dion. Perieg.7-9 from the Latin translation. The (metrical) Greek of line 9 reads $\pi \rho \omega ́ \tau \eta \nu \mu \varepsilon \dot{\nu} \Lambda \imath \beta u ́ \eta \nu$,

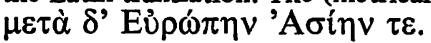


more strongly: I have easily found fourteen more references to add to his three. ${ }^{63}$ But this is not the whole story. These seventeen parallels are not representative of the whole pattern of usage. They are almost all drawn from Philo or from the geographers, and even in those writings they represent a limited contextual range. In nearly all cases Asia is explicitly set against Europe, and sometimes Libya (=Africa). The geographers only use this language when they are talking about continents in contradistinetion with ordinary usage. Strabo explains the double usage $(2.5 .25=$ p.126; $13.4 .2=$ p.624 $)$, and Ptolemy repeatedly refers to the province as 'Asia properly so called'. Philo, writing from an.Alexandrian perspective, uses '(the whole of) Asia and Europe (and Libya)' as a set phrase for the (rest of) the world, almost what Luke equates

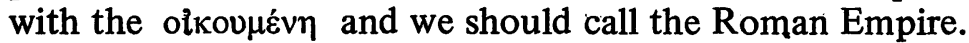
The only case I find outside these writings is in Plutarch, but where he is quoting a much earlier writer. Haenchen does not cite the only clear instance in Philo where there is no juxtaposition with Europe (ad Gaium 40.311): nor does he note that 'Asia' is used in the provincial sense in the context of one of the very passages he does quote (ad Gaium 36.281,

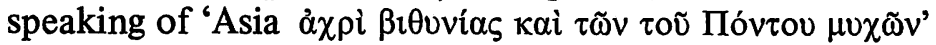
as distinguished from Pamphylia and Cilicia).

It is not the simple traditional question whether Luke (or Paul) always uses Roman provincial nomenclature. There is a variety of evidences that the concept of 'Asia' pervaded the Greek city life. Even in the Greek view Asia was an $\ddot{\varepsilon} \theta$ vos (CIG 2802.6, of Aphrodisias; $c f$. Acts 24:2, 10). We may cite as one instructive instance among many a catena of honorific inscriptions of the early second century relating to a group of interconnected persons from different cities whose services and benefactions are subsumed under their functions in the koinon of Asia. The cities thus united as 'Asian' in a cultural

63 Philo, Aetern. 141 (citing the Timaeus of Plato); ad Gaium 2.10; 4.22; 7. $48 ; 12.88 ; 21.144 ; 36.280 ; 40.311$ (the best example); Quod Omn. Prob. 14.94; 19.132 (about Persian Wars); Joseph 23.134; Moses 1.48.263; Plut. Mor. 1114B (in quotation from writer of 4th c. BC); Arrian, Periplus Ponti Euxini 29. So also in Latin, Lucan Phars. 2.674 (about time of Xerxes); 3.274-275. Note however that Philo himself uses 'Asia' in a narrower, perhaps the 'provincial', sense (e.g. ad Gaium 33.245, 250), and that he repeatedly uses the epithet $\delta \prime \eta \eta$ where he refers to the continent. 
framework so very Greek are Miletus on the coast, Apamea near the border of Galatian Phrygia, and Apollonia ad Rhyn-

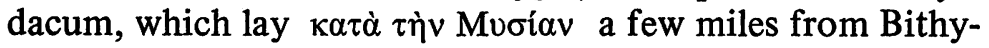
nia (Ramsay, $C B$ 2.pp.460-1, Nos. 291-3). My point is that 'Asia', rather like 'America' today, had a double usage, provincial area, or continent. We have to be guided by the feel and practice which a supposed eye-witness might have learned on the spot.

The narrative of Acts 16 does indeed pass rapidly over the details of the journey to Troas and focus attention upon the motif of the guidance and direction, negative and positive, of the Holy Spirit (so writers as diverse as Ramsay and Dibelius). ${ }^{64}$ The arrival at Troas, the postulated first meeting of Paul and Luke, and such matters, offer fruitful fields for speculation but will not be pursued here. My concluding remarks will review in the several early Christian texts the place of Troas in the patterns of travel and in the strategy of evangelism. It is I think a corroboration of the first-hand character of the 'we-passages' and other documents that they relate unemphatically to the local conditions in their circumstantial details.

Acts 16:6ff. The route of the journey to Troas is unresolved. Haenchen (Acts, p.486) follows the assumption of those who, since Ramsay, have drawn lines of route purposefully across the map, and speaks of a road from the interior ending at Troas. But no such road seems to be known. ${ }^{65}$ We have seen that Troas had a circumscribed hinterland and that the natural land communications of the Troad are peripheral. The likelihood of a direct Roman route at least from Troas to Scepsis has been corroborated by the recent discovery of a fragmentary milestone in the Scamander valley in line between the two cities. The numeral $X V$ is preserved on it: the stone

64 Ramsay, SPT 198; Dibelius, Studies in the Acts of the Apostles, SCM, London (1956) 129-130, tr. by M. Ling from German edition of 1951.

65 The assumed line of a road is drawn, for instance, on the maps in $H D B$, Extra Vol., following p.400, and in SPT, under back cover. In SPT 297 Ramsay mentions a tradition that Paul passed through a place Artemea at the hot springs of the Aesepus, and so at a point in the line of the postulated route, though east of the crucial part. Mr. Paul Bowers draws my attention to a reference in J.A.R. Munro, 'Explorations in Mysia', Supplementary Papers of the Royal Geographical Society 3 (1893) 20-21, where the writer adduces evidence for an east-west road across Mysia and cites circumstantial hints which might favour the supposition that a western continuation across the Troad existed in antiquity. No part of this however is likely to have been a major route. 
is eighteen miles from Troas and over thirteen from Scepsis, but certainly not in situ (G.E. Bean in Cook, pp.396-7). That is the limit of the apparent evidence. It must be considered an open question whether Paul's haste to Troas brought him over some rugged path which linked with this or whether he came round the northern or southern coastal roads of the Troad. The pattern of this journey is not yet clear. ${ }^{66}$

In the sequel Paul's vision is followed by immediate action to secure a passage to Macedonia. The verb $\varepsilon \dot{0} \theta 0 \delta \rho \circ \mu \eta \dot{\sigma} \sigma \alpha \mu \varepsilon v$ in verse 11 takes up $\varepsilon \dot{u} \theta \varepsilon \dot{c} \omega s$ in verse 10: the call of God to Macedonia was confirmed in Luke's view by the easing or veering of the winds to permit a direct and immediate crossing in two days.

2 Corinthians 2:12. The next reference, according to the ostensible chronology, is in Paul's own Hauptbrief. Yet historical problems are no less apparent here. There is first the problem of the sequence and chronology of the Corinthian correspondence, and of the unity and setting of 2 Corinthians in particular. Secondly, there is the question whether the Acts narrative can, or should, be harmonized with this. The first problem is highly complex, but touches our present point

\footnotetext{
66 This problem, noted above, seems unresolved. Troas was not the line of least resistance, but looks like a chosen destination, involving the rejection of nearer and easier paths. Yet on arrival Paul is undecided about his next move. Was he consciously and boldly feeling his way towards the strategic route westward to Rome, or simply aiming at Troas as the best point for finding a sea passage elsewhere, perhaps back to the East? And how far did he appreciate at this stage the strategic position of Troas itself, though it were for the present comprehended in the area of the preaching ban? Then there is a problem in the ban itself: one might speculate whether the veto of the Holy Spirit was conjoined in Paul's mind with some indication that the provincial authorities in Asia and in Bithynia were disposed to prevent or frustrate his work. His reputation as the occasion of civil disorder in the Galatian cities could have preceded him (cf. Acts 17:6, at Thessalonica), and he could have been influenced by the prospect of reprisals against converts: it was apparently under such indirect pressures that he later left Thessalonica prematurely. His first objective could then have been negative: to leave Asia as quickly and discreetly as possible for a new sphere as yet undetermined but for which Troas offered the best opening.

Such thoughts can be no more than guesses. They assume the 'provincial' view of 'Asia' and accord with the temporary nature of the ban, which might be removed in changed circumstances under new officials: it is notable that when Paul finally settled to work in the heart of 'Asia' he is represented as having enjoyed the friendship of some of its influential citizens (Acts 19:31). My point is that the journey to Troas merits explanation in terms of geography and raises questions of Paul's conception of his mission. These questions may in fact admit of no easy and certain answers from the limited data available, but they need to be raised.
} 
only marginally. Paul's plans of travel, we are to infer, had been changed more than once since the writing of 1 Corinthians (1 Cor. 16:5-8; 2 Cor. 1:15-16; 1:23ff.). Further developments in the Corinthian situation had necessitated the 'severe letter' ( 2 Cor. 2:4). Paul had then sent Titus ( 2 Cor. 7:5ff.; 12:18) to learn the Corinthians' reactions to his letter, and apparently intended to visit Corinth again himself if the report were favourable. He had been in Ephesus at the writing of 1 Corinthians, intending then to remain there until Pentecost (1 Cor. 16:8; probably $A D$ 55). Before writing 2 Corinthians 2:12 he had come to Troas 'to preach Christ's gospel'

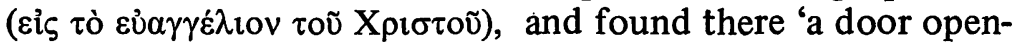
ed to me in the Lord', but his mind could not rest while he yet awaited Titus, so he took his leave and set out for Macedonia. There he finally met Titus on his return from Corinth, and was delighted at his report of the change of heart in the Corinthians. He will now carry out his desire to visit Corinth, confident that the painful incidents of a previous occasion will not be repeated ( $c f .2$ Cor. 13:1, 10, which I take to be not earlier than 2 Cor. 1-9). The way is presumably clear for him to resume the last part of his original plan to spend the winter (55-6) in Corinth, and sail from there in the spring for Jerusalem (cf. 1 Cor. 16:5-6; 2 Cor. 1:16b).

Troas was on Paul's way from Ephesus to Macedonia. On arrival there he found it a place so strategic that he made it a centre for his work, and was only shifted by his overriding involvement in the Corinthian controversy. The point is readily understood. Here was a Roman and cosmopolitan population, reinforced by temporary sojourners suffering enforced delays far from their homes in many parts of the Roman world. A Christian community in such a place would have wide influence. But if Paul were to have any prospect of spending needed time in Corinth he dare not risk being delayed or immobilized by the difficulty of winter travel. It may have been already late in the year when he made the seacrossing to intercept Titus.

The whole series of movements thus inferred from 2 Corinthians may be paralleled with the narrative of Acts 20:1-3. This makes no mention of the inner conflicts of the churches, of the motivations of the journey, or of the stay at Troas, but it records in outline the same progress from Ephesus through 
Macedonia to Corinth, where Paul is said to have stayed three months, intending then to sail to Syria.

There is to my mind no problem of harmonization here. The form and purpose of the two writings is here radically different. The references in Paul are allusive, and were struck out in the heat of a situation involving his readers: in Luke we have a brief external summary to set the scene for the focal journeys to Jerusalem and Rome.

Acts 20:4-14. The next 'we-passage' is also the occasion of the next appearance of Troas. This immediately follows another change of plan, when Paul determines to evade an ambush by returning overland through Macedonia on his way to Jerusalem (Acts 20:3). The narrator who left the action at Philippi reappears at the same place. Some of the party now assembled went ahead and awaited 'us' (that is, apparently, Paul' the narrator, and perhaps others) $^{67}$ at Troas. Paul's group stayed until after the days of unleavened bread following the Passover. Paul, we may presume, was concerned to take the opportunity of a brief pastoral visit to the Philippians while the advance party prepared his coming to Troas and his passage thence.

Time comes to play a large part in the succeeding narrative. Paul, we learn, had set himself the day of Pentecost to be in Jerusalem. On grounds of time he by-passed so important a centre as Ephesus (Acts 20:16). Yet after five days spent reaching Troas, he stayed seven days there. Perhaps he had to await a passage, though the prevailing winds favoured swift sailing in this southerly direction. But the sojourn in Troas is treated with a surprising fullness. Luke had not previously mentioned the evangelization of this city: we have to infer it from 2 Corinthians $2: 12$. Yet now we are given a vivid eyewitness scene.

I propose to say little of this Eutychus incident. But we are not to understand that it was Paul's usual practice to preach at such length. Nor should we follow Dibelius (pp.17-

67 There is no difficulty in the fact that 'we' in 20:5 and in 20:13 evidently include and exclude different persons: the meaning is simply 'the relevant section of the party including the narrator'. Note however Haenchen, pp.581-582. The important variant common to A, D, E and the TR, which include $\alpha \chi \rho i$ (D $\mu \varepsilon \chi \rho i) \tau \tilde{\eta} \varsigma$ 'A $\sigma i \alpha_{\zeta}$ in verse 4, is most simply explained as an explanatory gloss, without the need to resort to the supposition of a subtle reworking of an imagined difficulty. It is in any case harder to account for the omission of these words if they were original. 
19) and Haenchen (p.586) in seeing here a 'secular' anecdote interpolated by Luke into the 'we'-narrative. It is however relevant, I think, to point out the importance Paul is represented as attaching to the occasion. It might be his last opportunity in Troas, and he will use every possible moment remaining there to establish and instruct the infant church in a place so strategic. This is perhaps the point of his separate journey to Assos. The rest of his party, including the narrator, 'went ahead' by sea: Paul was able to stay later in Troas and then reach the ship at Assos at the last moment. A swift horse on the coastal route would take much less time than a coasting ship which had to round Lectum ( $\pi \varepsilon \xi \varepsilon v i \varepsilon v$ is used of 'land'travel by any means, and sometimes explicitly of travel on horseback). ${ }^{68}$

Journeys to and from Ephesus. I add a note here on a possible New Testament relevance of Troas on a point which I intend to discuss more fully elsewhere. The various Pauline 'imprisonment epistles' have been diversely ascribed to imprisonments, recorded or inferred, at Ephesus, Caesarea, or Rome. Philippians, in particular, whose occasion seems to differ widely from that of the others, is often attributed to a putative imprisonment in Ephesus. It is implied that Paul had already been a considerable time in prison, and that communications had already passed to and fro which required time for perhaps three or more journeys by his associates between the prison and Philippi. As Ephesus is so much nearer Philippi than is Rome, this factor offers an appealing prima facie argument for the Ephesian hypothesis. In that case the facility for travel through Troas would assume a relevance to the question.

I have become increasingly convinced that Philippians was in fact written from Rome near the end of Paul's 'two years' there (Acts 28:30). The point is not, I think, to be settled by the simple application of differences of travelling time. There are other arguments for Rome, and there are difficulties in postulating a suitable imprisonment in Ephesus. On the travel point, I suggest that the communication was feasible through

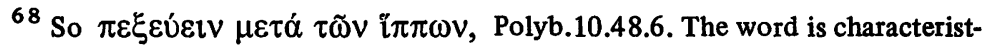
ically opposed to 'sea'-travel (as here). It is used of crossing the sea itself dry-shod, as Xerxes had crossed the Hellespont by a bridge of boats (Isocr.4.89; Polyb. 16. 29.11; Lucian, Rhet. Praec. 18). 
the utilization of regular facilities, perhaps by Christians 'of Caesar's household' (Phil. 4:22), known to the Philippians because they came through Philippi on official business on their way to or from Rome. The position of Philippi on the direct postal route made habitual communication with Rome possible, but from Ephesus the habitual route, when the season permitted, was across the Aegean to Corinth. If it were not regularly through Troas and Philippi, this simpler journey may have hinged far more on the possible expenses and delays of chartering a personal passage.

2 Timothy 4:13. The incidental reference to Troas in this verse is again at a significant point. The authenticity of this mundane request for a cloak, and for books and parchments, is widely conceded. ${ }^{69}$ The problem here is the setting of the passage. I shall not pursue the matter here. There is one simple observation to be made: the impression is one of hasty, perhaps enforced, departure, making it impossible for Paul to bring essential warm clothing and important documents. It is at least a plausible guess that he was suddenly arrested there, and hurried on board ship from Troas at a time when the weather permitted. Timothy will pass through Troas on his way to come to Paul before winter (2 Tim. 4:21). It seems likely that the journey involved is from Asia to Rome ( $c f$. 4:20). Sudden embarkation from Troas to travel westwards is a recurring theme. We meet it again in our next and last instance.

The evidence of Ignatius. Three of the seven generally accepted epistles of Ignatius, those to the Philadelphians, to the Smyrnaeans, and to Polycarp, were written from Troas (Ignat. Philad. 11;Smyrn. 12; Polyc. 8). In his final letter, that to Polycarp, Ignatius concludes with the regret that he cannot write to all the churches 'because of his hurried sailing

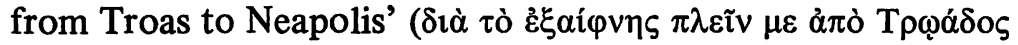
$\varepsilon i \zeta \varsigma$ Neá $\pi 0 \lambda$ iv). He accepts this as God's will, and asks Polycarp to direct the churches on his behalf to send letters or messengers to Syria.

Ignatius was going to Rome as a prisoner. His escort, like so many others, was obliged to wait at Troas for their passage. It was this delay which gave the prisoner his opportunity to

\footnotetext{
${ }^{69}$ Thus notably P.N. Harrison, The Problem of the Pastoral Epistles, Oxford UP (1921).
} 
write to those two churches he had most recently had a brief chance to visit en route. But when the weather permitted a ship to sail, the chance of departure had to be taken quickly, and the captive had no choice. ${ }^{70}$

Walter Bauer, in his influential study Orthodoxy and Heresy in Earliest Christianity (Rechtgläubigkeit und Ketzerei im ältesten Christentum), ${ }^{71}$ has built an elaborate structure here on a series of arguments from silence. First the writer of the Revelation, and then Ignatius, addressed only those churches which were likely to grant a hearing: it is inferred that others were in the control of other versions of Christianity which were stigmatized as heretical only when their opponents prevailed. ${ }^{72}$ But the choice of the seven apocalyptic cities is, I am sure, to be explained otherwise, and the situation which may be uncovered by the study of their background appears to differ widely from that which Bauer postulates. ${ }^{73}$ So with Ignatius: we can understand why he was so concerned to write to Smyrna and Philadelphia, and he tells us himself he had no opportunity to write to others. I submit that the simplest explanation of the omission is correct. We have no warrant for building a historical and theological structure upon unnecessary suppositions.

Conclusion. This is an appropriate note on which to conclude with a plea that we seek to take all the aspects of a problem into account, and to evaluate the differing applicability of the different techniques of criticism to the individual case. The circumstantial anomaly and the ostensible historical narrative are sometimes amenable to different kinds of explanation. The same point may appear a flaw of literary composition or an authenticating fragment of history. Judgements will sometimes differ. I have tried to put a group of texts into their presumed context in the lives of Luke, Paul and Ignatius, and to illustrate their relation to the circumstances of their original travel. I suggest that a pattern emerges, however faintly. This is not to question the importance of

${ }^{70}$ Cf. J.B. Lightfoot, The Apostolic Fathers. Ignatius and Polycarp 1.36.

71 Tr. and ed. by R.A. Kraft and G. Krodel from 2nd German ed. of 1964, Fortress Press, Philadelphia (1971).

72 Bauer, pp.77ff.

73 See further C.J. Hemer, A Study of the Letters to the Seven Churches of Asia with Special Reference to their Local Background, Manchester PhD thesis (1969), to be published in SNTS. 
theological study of theological texts. But I sometimes fear that in our haste to eschew a dated historicism we allow theological concern to overrule its necessary complement in historical study.

\section{APPENDIX I}

Bibliography of Troas

(a) References in ancient literature: Polyb. v. 111. 3-4; xxi.13.3; xxi.14.2; Diod Sic. xxix.7; Liv. xxxv.42.2; xxxvii. 35.2 (and cf. $x x x v .16 .3-5$ ); Strab. ii. $5.40=$ p. $135 ; x$ iii. $1.26=$ p. $593,33=$ p. $597 ; 47=$ p. $604 ; 52=$ p. 607 .

Acts $16: 8-11 ; 20: 5-12 ; 2$ Cor. $2: 12 ; 2$ Tim. 4:13.

Plin. N.H. v.33.124.

Ignat. Philad. 11; Polyc. 8; Antiochene Acts of Ignat. 5.

Suet. Caes. 79.3 (cf. Hor. Od. iii.3.57-68); App. Syr. 29; Ptol. Geog. v.2.4; viii.17.9; Athen. Deipn. iii.80d. iv.155b; ix.393d (cf. Strab. xiii.1.27 = p.594 for Hegesianax); Philostr. Vit. Soph. ii.1.548; Zonaras xiii.3; Zosimus ii.30.2; Steph. Byz. 'Alexandreia'.

(b) Coinage and numismatic literature:

The basic work is Catalogue of the Greek Coins of Troas. Aeolis and Lesbos in the British Museum, ed. W. Wroth (Lon (London, 1894), Alexandria Troas (189 items), with Introduction, xiv-xix.

See also: J. de Witte, 'Apollo sminthien', Revue. Numismatique, nouv. sér., III (1858) 1-51:

B.V. Head, Historia Numorum, 1st ed. (Oxford, 1887) $=$ 538-9; 2nd ed. (1911) = 540-1.

F. Imhoof-Blumer, Kleinasiatische Münzen (Vienna, 1901) I.35-6 and II.507.

G. Macdonald, 'Early Seleucid Portraits', JHS 23 (1903) 92-116.

Sylloge Nummorum Graecorum (London, 1931-), I.ii.246; III.iv.2731; IV.vi.4253-80.

J.G. Milne, 'Notes on the Oxford Collection'. (2) Mysia, Troas and Aeolis', Numismatic Chronicle, 5th ser., 16 (1936) 281-7.

L. Robert, Monnaies antiques en Troade (Hautes Etudes numismatiques), (Geneva and Paris, 1966).

M. Thompson, 'The Mints of Lysimachus', Essays in Greek 
Coinage Presented to Stanley Robinson, ed. C.M. Kraay and G.K. Jenkins, Oxford (1968) 176-7

H. Seyrig, 'Monnaies hellénistiques. XIV. Statères d'or pseudalexandrins', Revue numismatique, 6th ser., 11 (1969) 36-9.

(c) Inscriptions and epigraphic literature:

CIG 3577-94.

CIL III.380-97, 413, 6060-3, 7071.

IGRR IV.243-6.

P. Le Bas and W.H. Waddington, Voyage archéologique en Grèce et en Asie Mineurs (LBW) (Paris, n.d., ?1843), Nos. 1035-7, 1730a-40.

W.M. Ramsay, 'Neryllinus', CR 48 (1934), 9-13.

L. Robert, 'Inscriptions grecques d'Asie Mineure. III Inscriptions de Troade', Anatolian Studies Presented to William Hepburn Buckler, ed. W.M. Calder and Josef Keil, Manchester (1939) 245-8.

W.M. Ramsay, The Social Basis of Roman Power in Asia Minor, Aberdeen (1941) 20-1.

M.N. Tod, 'The Corrector Maximus', ibid. 333-44.

Revue des études grecques 81 (1968) 502, No. 434 [Smintheum].

(d) Early Travellers:

G. Sandys, A Relation of a Journey Begun An: Dom: 1610, London (1615) 22-3.

J. Spon and G. Wheler, Voyage d'Italie, de Dalmatie, de Grèce et du Levant, 2 vols. The Hague (1724) I.118-20.

R. Chandler, Travels in Asia Minor, London (1775) 22-9.

Comte de Choiseul-Gouffier, Voyage pittoresque de la Grèce, 2 vols. Paris (1782-1809) II.434-8 [plans and drawings].

J.B. Lechevalier, Voyage de la Troade, 3 vols. Paris (1802) I.236-47 [valuable details] .

J.C. Hobhouse, A Journey through Albania and Other Provinces of Turkey in Europe and Asia, London (1813) 689715 [large scale map of district] .

E.D. Clarke, Travels in Various Countries of Europe, Asia and Africa, London (1817) III.191-6 [ careful copies of inscriptions].

J.A. Cramer, A Historical and Geographical Description of Asia Minor, Oxford, 2 vols. (1832) I.114-15.

C. Fellows, A Journal Written during an Excursion in Asia 
Minor, London (1839) 58-61.

(e) Encyclopaedia articles: The most important are:

W.J. Woodhouse, 'Troas', EB IV.5214-15.

W.M. Ramsay, 'Troas', $H D B$ IV.813-14.

Hirschfeld, 'Alexandreia Troas' (Alex. No. 16), RE I.i.1396.

(f) General Literature:

A.H. Sayce, 'Notes from Journeys in the Troad and Lydia', JHS 1 (1881) 75-93, esp. 81-3.

C. Texier, Asie Mineure, Paris (1882) 194-7.

R. Koldewey, 'Das Bad von Alexandria Troas', Athenische Mittheilungen 9 (1884) 36-48.

W.M. Ramsay, 'The Denials of Peter. Excursus to Section III. The House in the New Testament', ET 27 (1915-16) 471-2.

W. Leaf, Strabo on the Troad, Cambridge (1923) xxxi-xxxii, 141-4, 221, 233-40.

A.H.M. Jones, Cities of the Eastern Roman Provinces, Oxford (1937) 42, 385.

L. Robert, Hellenica. Receuil d'épigraphie, de numismatique et d'antiquités grecques, II, Paris (1946) 67-8.

E.V. Hansen, The Attalids of Pergamon (Cornell Studies in Classical Philology XXIX), Ithaca, N.Y. (1947) 42-3, 73-4, 207-8.

D. Magie, Roman Rule in Asia Minor, Princeton (1950) esp. I.69, 82-3, 92; II.875, 923.

J.M. Cook, The Troad. An Archaeological and Topographical Study. Clarendon Press, Oxford (1973).

(g) District and Background:

J. Thacher Clarke, 'A Proto-Ionic Capital from the Site of Neandreia', American Journal of Archaeology 2 (1886) 1-20 and 136-48.

W. Leaf, Troy. A Study in Homeric Geography, London (1912) $118-20$ and passim.

W. Leaf, 'Some Problems of the Troad', Annual of the British School at Athens 21 (1914-16) 16-30 (28-30 for Hamaxitus).

W. Leaf, 'The Military Geography of the Troad', Geographical Journal 47, (1916) 401-16.

W. Leaf, 'Notes on the Text of Strabo XIII.1', JHS 37 (1917) 19-30.

W. Leaf, 'Skepsis in the Troad', Anatolian Studies Presented to Sir William Mitchell Ramsay, ed. W.H. Buckler and W.M. 
Calder, Manchester (1923) 267-81.

W. Leaf, Strabo on the Troad, Cambridge (1923) passim.

Bürchner, 'Hamaxitos', $R E$ VII.ii.2296-7.

J.M. Cook and G.E. Bean, Report on survey in the Troad, Anatolian Studies 10 (1960) 28 (site of Hamaxitus); cf. 17 (1967) 32; 19 (1969) 20.

(h) Local Religion: the cult of Apollo Smintheus.

A.D. Godley, ' $\Sigma \mu \mathrm{t} v \theta \varepsilon \varepsilon^{\zeta}$ ', CR 15 (1901) 194.

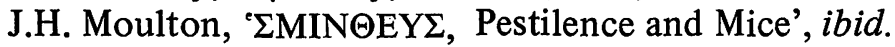
284.

A.T.C. Cree, ${ }^{\circ} \Sigma M I N \Theta E Y \Sigma$, Pestilence and Mice', ibid. 2845.

A. Lang, 'Apollo Smintheus, Rats, Mice and Plague', ibid. 319-20.

J. Rendel Harris, 'The Origin of the Cult of Artemis', BJRL 3 (1916-17) 147-84; see 173-5.

L.R. Farnell, The Cults of the Greek States IV 162-166.

For details of other cities of the district see further the relevant sections in the British Museum catalogue of Greek coins and in the inscriptional Corpora.

\section{APPENDIX II}

\section{NOTES ON SOME ANCIENT VOYAGES}

The following group of incidents, some of which are briefly noted in the text of the paper, are collected here for convenience, and to give some partial illustration of the prevalent patterns of wind and weather in the area. I have no doubt that further search could greatly extend the evidence.

(1) Odysseus, after finally leaving Troy, reaches the Cicones at Ismarus in Thrace with a favouring wind (Hom. Od. 9.39), but on escape from the slaughter of his men is driven helpless before a northerly gale (9.67-68). (The Odyssey shows understanding of navigational realities: the time of departure from Troy could be chosen; that from Ismarus was enforced. It is assumed without question that the ship has no option but to run before a strong wind.)

(2) The Spartan admiral Astyochus has most of his ships driven back from the Hellespont in an attempt on Byzantium: only ten ships arrived; but rest were forced to take refuge at Delos (Thuc. 8.80). 
(3) The Spartan admiral Mindarus attempts to take seventythree ships from Miletus to the Hellespont, but is driven into Icarus by a storm and detained there for five or six days (Thuc. 8.99). Later he succeeds in stealing out of Chios and makes a swift coasting course inside Lesbos, thereby eluding an Athenian squadron at Eresus (8.101).

(4) Conversely, Lucan (Phars. 9.1000-1005) records a sevenday voyage from Troy to Alexandria in Egypt with the prevalent (NW) winds of the Eastern Mediterranean (Zephyro numquam laxante, 1004).

(5) Pliny writes to Trajan of the progress of his journey to Bithynia. At Ephesus he plans to proceed partly by land, partly by sea: he is confronted by the adverse Etesians by sea, and the extreme of heat by land: Quamvis contrariis ventis retentus, nunc destino partim orariis navibus, partim vehiculis provinciam petere. Nam sicut itinere graves aestus, ita continuae navigationi etesiae reluctantur (Ep. 10.15). Later the heat of the overland stage brought on a fever which kept him in Pergamum. And when he transferred to a coasting vessel he was again detained by the winds: Rursus, cum transissem in orarias naviculas, contrariis ventis retentus, aliquanto tardius, quam speraveram, id est XV Kal. Octobres, Bithyniam intravi (10.17a).

(6) Josephus (Antiq. 16.2.2.17-20) recounts how Herod sailed in spring to join Agrippa for his Bosporan expedition. He sailed between Rhodes and Cos in the endeavour to overtake Agrippa at Lesbos, but a $\pi v \varepsilon \tilde{\mu} \mu \alpha$ ßopeĩov caught him

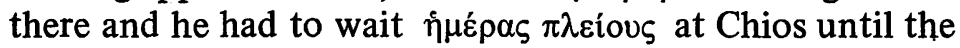
wind died down, eventually joining his friend at Sinope.

\section{ABBREVIATIONS}

BMC Catalogue of the Greek Coins of Troas, Aeolis and Lesbos in the British Museum, ed. W. Wroth, Brit. Mus., London (1894).

CJ The Classical Journal

CR The Classical Review

EJ V. Ehrenberg and A.H.M. Jones, Documents Ilustrating the Reigns of Augustus and Teberius ${ }^{2}$, Clarendon, Oxford (1954).

IGRR Inscriptiones Graecae ad Res Romanas Pertinentes.

JTC Journal for Theology and the Church.

OGIS Orientis Graecae Inscriptiones Selectae.

TAPA Transactions of the American Philological Association. 